\title{
Łucja Frey-Gottesman - autorka zespołu Frey i jej tragiczne losy
}

\author{
Barbara Emeryk-Szajewska \\ Klinika Neurologiczna, Warszawski Uniwersytet Medyczny
}

Dzieje Łucji Frey są skomplikowane i niejasne, zwłaszcza ostatni okres jej życia podczas II wojny światowej - kiedy przebywała w getcie lwowskim - kryje wiele niewiadomych: nie udało się ustalić daty ani okoliczności jej śmierci, nie wiadomo, czy zginęła w getcie, czy została wywieziona do obozu zagłady w Bełżcu i tam zginęła, nie wiadomo, co stało się z jej rodziną. A przecież była wybitnym lekarzem neurologiem, autorką wielu publikacji, a przede wszystkim zespołu objawów nerwu małżowinowo-skroniowego (n. auriculo-

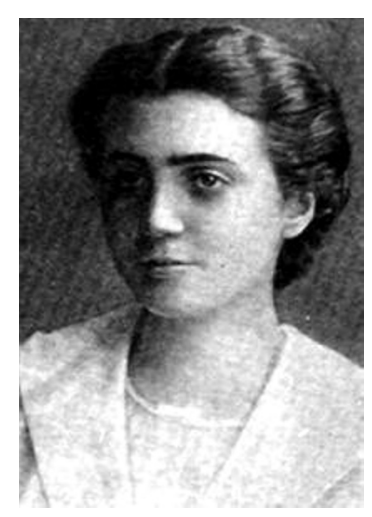

Ryc. 1. Łucja Frey, rok 1918

Weinreb. Ojciec był dostawcą budowlanym, matka nie pracowała zawodowo. Była to dość zamożna rodzina zasymilowanych Żydów. W domu mówiono po polsku i Łucja za swój ojczysty język podawała polski. Edukację rozpoczęła w katolickiej szkole powszechnej przy klasztorze benedyktynek, dokąd uczęszczała w latach $1896-$ 1900. Po jej ukończeniu została przyjęta do prywatnego żydowskiego gimnazjum dla dziewcząt Goldblatt-Kammerling, które ukończyła w roku 1907. W tym samym roku zdała jednocześnie egzamin dojrzałości (jako ekstern) w państwowym wej zespołem Frey. Toteż podejmowano próby ustalenia jej biografii. W roku 2004 Miriam Moltrecht, w Niemczech, napisała o niej obszerną, bo liczącą 106 stron, dysertację doktorską zatytułowaną Eucja Frey - Rekonstruktion eines Lebens. Przygotowując doktorat, autorka zebrała wszystkie dostępne w piśmiennictwie materiały dotyczące dorobku naukowego, przebiegu pracy zawodowej i dane biograficzne Łucji Frey. Kompletując te ostatnie, natrafiła na duże trudności. Dlatego nawiązała kontakt z ponad 100 ośrodkami i drogą korespondencyjną próbowała zebrać potrzebne informacje. Jak podaje, były to uniwersytety, biblioteki, medyczne towarzystwa naukowe w Polsce, Ukrainie, Austrii, Rosji, Stanach Zjednoczonych, Izraelu, Wielkiej Brytanii i Niemczech, ponadto naukowo-badawcze instytuty żydowskie, Instytut Yad Vashem, instytuty zajmujące się holokaustem $\mathrm{i}$ inne. Otrzymała wartościowe materiały zaledwie z 5 ośrodków.

Pracę tę w wersji skróconej, wspólnie z Olafem Michelem, opublikowała pod tytułem The Woman behind Frey'Syndrome: The Tragic Life of Eucja Frey [2]. Obie te prace stanowity podstawę obecnego opracowania $[1,2]$.

\section{Życiorys}

Łucja Frey urodziła się 3 listopada 1889 r. we Lwowie jako córka Szymona Symchy Freya i Diny z domu gimnazjum Franciszka Józefa. Rozpoczęła studia na Uniwersytecie Lwowskim na wydziale filozoficznym oraz matematycznym. Matematykę studiowała pod kierunkiem prof. Mariana Smoluchowskiego, znakomitego matematyka (1908-1912). W swoim życiorysie, własnoręcznie napisanym, podała, że w 1913 r. zdała egzaminy nauczycielskie, uprawniające do nauczania matematyki w szkole średniej. Studia medyczne na Uniwersytecie Lwowskim podjęła najprawdopobniej dopiero w roku 1917, aczkolwiek w licznych źródłach istnieją rozbieżności co do terminu ich rozpoczęcia. Przerwała je w 1918 r. w związku z sytuacją polityczną i walkami polsko-ukraińskimi we Lwowie. Po ustabilizowaniu się sytuacji politycznej w 1919 r. otrzymała obywatelstwo polskie, bo do tego czasu, jak większość ludności zamieszkującej tereny dawnego zaboru austriackiego, miała obywatelstwo austriackie. W tym czasie, jako studentka, pracowała pod kierunkiem prof. Kazimierza Orzechowskiego na oddziale nerwowo-psychiatrycznym w Szpitalu Krajowym we Lwowie. W roku 1920 prof. Orzechowski został kierownikiem nowo utworzonej Kliniki i Katedry Neurologicznej w Warszawie i prawdopodobnie zaproponował Łucji Frey dalszą współpracę. Zdecydowała się ona na zmianę uczelni i po kilku semestrach studiów we Lwowie przeniosła się na dalsze studia na Uniwersytet Warszawski. Studia te ukończyła w 1921 r., zdając znakomicie, z ocenami bardzo dobry- 
mi i celującymi, egzaminy końcowe; dyplom otrzymała w 1923 r., w wieku 34 lat. Przez cały czas pobytu w Warszawie, również w okresie studiów, pracowała w Klinice Neurologicznej u prof. Orzechowskiego, początkowo jako młodszy asystent, a po uzyskaniu dyplomu, jako starszy asystent. W tym czasie mieszkała w bu dynku Kliniki Neurologicznej, w szpitalu Dzieciątka Jezus przy ul. Nowogrodzkiej 59, cały swój czas oraz niepospolitą energię i pracowitość poświęcając pracy naukowej. Wszystkie jej publikacje i cały dorobek naukowy pochodzą z tego okresu, obejmującego właściwie kilka lat: 1923-1928. Jej dorobek naukowy zostanie przedstawiony dalej. W roku 1929 podjęła decyzję powrotu do Lwowa, najprawdopodobniej z przyczyn osobistych: wyszła wówczas za mąż za Marka Gottesmana, adwokata, z którym, jak wydaje się, była związana od wielu lat. Rok później, w 1930 r., urodziła córkę Danutę. Według relacji jej szwagierki Hedwy Balat (z domu Gottesman), złożonej w roku 1955 w Instytucie Yad Vashem, było to jej drugie dziecko; w 1919 r. urodziła jakoby pierwszego syna Marka Gottesmana, Jakuba. O losach tego dziecka nic nie wiadomo. Od roku 1929 pracowała jako lekarz w Szpitalu Gminy Wyznaniowej Żydowskiej we Lwowie i jako starszy konsultant w poradni neurologicznej we Lwowie. Druga wojna światowa zastała ją we Lwowie. 19 września wojska radzieckie wkroczyły do miasta i rozpoczęła się okupacja. Wkrótce aresztowano męża Łucji, Marka Gottesmana, pod zarzutem działalności antykomunistycznej, i od tego czasu słuch o nim zaginął, nigdy nie otrzymano informacji o jego losie. 30 czerwca $1941 \mathrm{r}$. wojska niemieckie zajęły Lwów i Łucja Frey znalazła się w getcie. W tym czasie nadal pracowała w II Klinice Szpitala Żydowskiego (II Ghettopoliklinik). Ostatnia wiadomość o niej pochodzi z 1 kwietnia 1942 r.: jest to wypełniony kwestionariusz osobowy w celu otrzymania karty pozwolenia o pracę o numerze porządkowym 144, wystawiony przez władze niemieckie. Był to rodzaj „zielonej karty”, dającej nadzieję przeżycia. 20 sierpnia 1942 r. prawie wszyscy pacjenci i personel medyczny kliniki w getcie, ok. 400 osób, został wymordowany, być może wśród tych osób była Łucja Frey. Jeśli ocalała, to prawdopodobnie w sierpniu 1942 r. została deportowana do obozu zagłady w Bełżcu i tam zginęła. W czerwcu 1943 r. władze niemieckie dokonały ostatecznej likwidacji getta lwowskiego i niektóre opracowania podają ten rok jako rok śmierci Łucji Frey [3,4]. Nie wiadomo również nic o losach jej rodziny: męża, córki Danuty, domniemanego syna Jakuba, rodziców i teściów.

\section{Dorobek naukowy}

Pierwsze wspomnienie o Łucji Frey-Gottesman pochodzi z roku 1950: jest to Wspomnienie pośmiertne pióra Eufemiusza Hermana, opublikowane w Neurologii Polskiej [3]; w 1958 r. ukazała się jego książka Neurolodzy Polscy, w której zamieszczony jest rozdział poświęcony Łucji Frey. Herman pisze o niej: „Nad wyraz skromna, cicha, o mrówczej pracowitości, odznaczała się w stopniu niemałym inwencją twórczą. Wszystkie jej prace naukowe cechuje niezwykła dokładność, dążenie do wszechstronnego poznania badanego zagadnienia oraz poważna znajomość przedmiotu. Dowodem najlepszym tego jest jej praca poświęcona zespołowi objawów nerwu małżowinowo-skroniowego (n. auriculotemporalis). Praca ta wprowadziła od razu nazwisko Freyówny, tego młodego podówczas neurologa, do neurologii światowej (1923)". Dorobek naukowy Łucji Frey nie jest duży, obejmuje 43 prace opublikowane $\mathrm{w}$ piśmiennictwie polskim i zagranicznym (francuskim). Wszystkie te prace pochodzą ze stosunkowo krótkiego okresu, z lat 1923-1928, kiedy pracowała w Klinice Uniwersytetu Warszawskiego; był to okres jej wytężonej pracy naukowej. Później, po powrocie do Lwowa, zajęła się głównie lekarską działalnością praktyczną. A potem przyszła wojna i okupacja niemiecka...

Z prac Łucji Frey najbardziej znany jest opisany przez nią zespół uszkodzenia nerwu małżowinowo-skroniowego. Polega on na odruchowych zaburzeniach układu potowydzielniczego i naczynioruchowego twarzy, w zakresie inerwacji uszkodzonego nerwu małżowinowo-skroniowego: $\mathrm{u}$ chorego podczas przyjmowania pokarmów kwaśnych, gorzkich, twardych lub gorących występuje napad silnego pocenia i zaczerwienienia połowy twarzy. Prawdopodobną przyczyną jest uszkodzenie tego nerwu w obrębie ślinianki usznej w wyniku procesu zapalnego, blizny pozapalnej, urazu lub zabiegu chirurgicznego ślinianki [4]. Już poprzednio pojawiały się w piśmiennictwie podobne opisy (Kastremsky 1740, Dupuy 1816, Brown-Sequard 1849, Botkin 1875 $\mathrm{i}$ inni), były one jednak fragmentaryczne i nie analizowały możliwego patomechanizmu tego zespołu, a zwła- 
szcza tzw. pocenia smakowego [5]. Praca Le Syndrome du Nerf Auriculo-Temporal to pierwsze pełne przedstawienie tego zespołu w piśmiennictwie światowym [6]. Nazwę zespołu Frey wprowadzili do literatury medycznej Higier (1926) i Bassoe (1932), podkreślając, że Frey pierwsza zwróciła uwagę na uszkodzenie zarówno włókien współczulnych, jak i przywspółczulnych w tym zespole [5]. Znajomość tego zespołu jest ważna zarówno dla neurologów, jak laryngologów i chirurgów. Doskonały jest zespół prac autorki dotyczący topografii pnia mózgu, świadczący o jej znajomości struktur anatomicznych i histopatologicznych układu nerwowego i wzbogacajaccy o nowe dane korelacje anatomo-kliniczne. Na specjalną uwagę zasługuje też praca poświęcona zmianom anatomicznym w chorobie Charcota wykonana wspólnie z Kazimierzem Orzechowskim (1925): autorzy wykazali w niej, że w stwardnieniu zanikowym bocznym zmiany histologiczne są obecne w róż nych obszarach kory mózgowej, a nie tylko w korze ruchowej, dotyczą one zwłaszcza warstwy V i VI kory. W rdzeniu kręgowym zmiany znajduje się w całej istocie szarej, łącznie z istotą żelatynową. Autorzy na podstawie własnych badań wysunęli hipotezę pochodzenia toksycznego lub zapalnego tej choroby [4]. Spuścizna autorki zawiera też interesujacce prace m.in. o wpływie trucizn roślinnych na powstawanie fibrylacji i zmiany zwyrodnieniowe rdzenia kręgowego, opisy kazuistyczne tętniaka splotu tętniczego rdzenia, torbieli trzeciej komory mózgu, guzów stoku, płata czołowego i guzów retrosplenialnych ciała modzelowatego. Wspólnie z Adamem Opalskim, neuropatologiem, opublikowała również pracę poświęconą dziedzicznym chorobom układu nerwowego [7]. Profesor Eufemiusz Herman w swojej książce pisze: „Chociaż spuścizna naukowa Łucji Frey nie jest zbyt wielka, to jednak każda jej praca opublikowana posiada duży ciężar naukowy, pozostawiając w światowym dorobku naukowym trwały ślad" [4].

\section{Piśmiennictwo}

1. Moltrecht M. Łucja Frey - Rekonstruktion eines Lebens, Dissertation an der Medizinischen Fakultät der Universität Leipzig, 21 Dezember 2004.

2. Moltrecht M., Michel O. The woman behind Frey's syndrome: the tragic life of Łucja Frey. Laryngoscope 2004; 114: 2205-2209.

3. Herman E. Wspomnienie pośmiertne. Neurol Pol 1950; 24: 27-28.

4. Herman E. Neurolodzy polscy. PZWL, Warszawa 1958, ss. 225-227.
5. Wikipedia, wolna encyklopedia, Łucja Frey-Gottesman. http//pl. Wikipedia.org/wiki/\%C5\%81ucja_Frey-Gottesman.

6. Frey L. Le syndrome du nerf auriculo-temporal. Rev Neurol 1923; II: 97-104.

7. Frey Ł., Opalski A. Przyczynki kliniczne do studjum nad schorzeniami dziedzicznymi układu nerwowego. Pol Gazeta Lek 1927; 15: 277-280. 